\section{Claiming Society for God: Religious Movements and Social Welfare, by Nancy J. Davis and Robert V. Robinson}

Bloomington: Indiana University Press, 20I2 $\mid$ xvi $+2 \mathrm{I} 4$ pages | ISBN: 978-0-253-00338-9 (softcover) \$25.00

Studying four doctrinally conservative religious movements, the Salvation Army in the United States, Shas $\lim$ Brotherhood in Egypt, this is an important book that will likely become a heavily cited contribution to the study of religious social movements and the relationship between religion, politics and the modern state. The book builds on Davis and Robertson's earlier quantitative studies of cultural and economic attitudes amongst the religiously orthodox in the United States and elsewhere. Drawing on large scale survey data, the authors found that not only did orthodox religiosity correlate with conservative anti-individualist attitudes in fields such as sexuality, but there was also a certain correlation with egalitarian economic attitudes; the religiously orthodox tend to be a little more supportive of economic redistribution and intervention. What those quantitative studies could not do, however, was thoroughly elucidate the relationship between the constitutive aspects of orthodox communitarianism; what the authors refer to here as religious orthodoxy's "caring" side (the Salvation Army's homeless shelters, the Muslim Brotherhood's dental clinics, Comunione e Liberazione's prison house patisseries and so on) with its culturally conservative authoritarian side (rejection of homosexuality, commitment to censorship, and gender segregation within Jewish and Islamic orthodoxy). Drawing primarily on existing social scientific studies, and a good amount of journalistic analysis, the present book elucidates the specific communitarian worldviews and outreach of the four groups, showing how conventionally egalitarian and non-egalitarian attitudes co-exist.

The central thesis is that orthodox religious movements "bypass the state" in attempts to moralize and transform society from below, or at the very least through civil society and commercial networks, rather than seeking to directly seize political and state power. The thesis is convincing insofar as it fits the data for each of the four groups, and for various others one might think of such as the Turkish-based Gulenist Islamic movement, Catholic Worker, 
and so on. Yet the authors admit on the final two pages (I 49-I 50) that the strategy of bypassing the state and operating with radically transformative intentions within civil society is hardly unique to orthodox religious groups; it is also common to secular radicals and idealists whose programs have limited appeal or efficacy. Moreover the thesis of bypassing the state to moralize and transform society fits each of the four case studies differently, the process "taking a variety of forms" (I 44), which might call its very utility into question since it can feasibly also apply to liberal religious groups, most of which are also civil society actors and service providers who dabble in public policy and aspire to inspire a society more in keeping with their ethical vision.

To illustrate potential difficulties with the flexibility of the thesis, compare the Muslim Brotherhood (chapter 2) and Comunione e Liberazione (chapter 4). Egypt's Muslim Brotherhood bypassed a state that, but for a comparatively short period, brutally supressed it. Allowed to operate freely in the political sphere in the two years between the fall of Mubarak and the re-establishment of the military's control over the country, the group's attempted "takeover of Egyptian civil society" (6o) became an attempted takeover of Egyptian society tout court. While Comunione e Liberazione shares with the Muslim Brotherhood a network of supportive businesses and commitment to building an extensive welfare infrastructure, it has sought to "diminish the role of the state" (97) and prove "there is no need for as extensive a state as currently exists" (I45) rather than capture the state to sacralise and redeploy its various apparatuses. Its foray into parliamentary politics was ended with voter apathy and corruption scandals (97-99) in rather typical Italian fashion, rather than the massacres and rounding up of the usual suspects that the Muslim Brotherhood suffered in rather typical Arab fashion. One can also contrast Shas (chapter 3), which hardly bypasses the state at all; it has used its kingmaker position in the Israeli Parliament to demand a large amount of state funding for schools and charities it runs autonomously but this autonomy is effectively a commodity extracted from the state through Shas's central role in successive governments $(70,85)$. It is not unreasonable to surmise that these situations, bypassing or finessing a relationship with the state to further the religious goals held by a minority of citizens, are merely the lot of religions in modern states (Italy, Israel and the United States) or modernising states (Egypt under the boot of the military) where a sufficient amount of religious and cultural diversity prevails and civil societies exist.

These concerns about the flexibility of the central thesis undermining its novelty or utility notwithstanding, this is an important book that will 
prove required reading in the study of religion and social movements; I am sure the chapter on the Muslim Brotherhood has already found its way onto undergraduate and graduate reading lists for courses on Islam and politics and the contemporary Middle East. The book is clearly written, explains or avoids jargon, and introduces complementary studies and theories and so would be well suited to undergraduate courses. I suspect the authors may have had this audience in mind which would explain the occasionally patronising tone. We are informed that the founder of Shas was born "in the Iraqi city of Baghdad" (65), as distinct from where, exactly? And we are burdened with journalistic introductions for the various scholars whose work is being cited, such as "Ann Lesch, a political scientist and associate provost for international programs at the American University of Cairo who was at Tahrir Square for the protests" (56). The book relies on previous sociological and political studies, and a significant amount of journalistic material and statements from the various groups, but the study is deceptively thorough given its scope and brevity. The book and its central thesis will likely provide the theoretical backbone for empirical studies in the future which may well clarify some of the ambiguities in the notion of "bypassing the state."

Ibrahim Abraham

University of Helsinki 